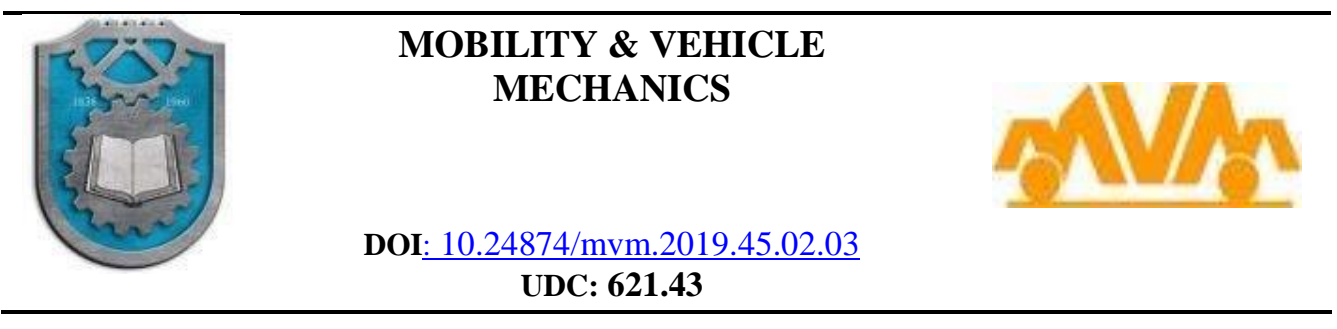

\title{
A PRELIMINARY ASSESSMENT OF RESIDENTIAL APPLICATION OF INTERNAL COMBUSTION ENGINE BASED COGENERATION IN SERBIAN CLIMATIC CONDITIONS WITH BUILDING SIMULATION PROGRAM
}

\author{
Novak Nikolić ${ }^{1 *}$, Nebojša Lukić $^{2}$, Nikola Milutinović $^{3}$, Aleksandar Nešović $^{4}$ \\ Received in February $2019 \quad$ Accepted in April 2019
}

RESEARCH ARTICLE

\begin{abstract}
In this paper the energetic and economic performance assessment of residential application of IC engine based cogeneration system in the Serbian climatic conditions using building energy simulation software was performed. The performance of IC based system was compared with the performance of the two other conventional systems for DHW preparation: gas and electric water heater. Comparing the IC based system with gas water heater the period required to return investment costs of IC engine is relatively high (11.7 years). The main barriers for widespread residential application of IC engine cogeneration system are related to the high capital costs and low price of purchased or sold electricity. In this respect, the investment cost reduction in small scale cogeneration systems has to be achieved. In relation to the current price in Serbia the price of purchased and sold electricity (feed-in tariff) should be increased by $37.5 \%$ and $67.5 \%$, respectively, in order to achieve the value of payback period of five years.

Comparing the IC based system with electric water heater the application of the IC engine is economically feasible since the payback period amounts 3.42 years. According to the simulation results, the IC engine cogeneration system ensured a primary energy saving of $28.81 \%$.
\end{abstract}

KEY WORDS: cogeneration, internal combustion engine, primary energy saving, dynamic simulation

(C) 2019 Published by University of Kragujevac, Faculty of Engineering

\footnotetext{
${ }^{I}$ Novak Nikolić, PhD Assist. professor, University of Kragujevac, Faculty of Engineering, Sestre Janjić 6, 34000 Kragujevac, novak.nikolic@ kg.ac.rs (*Corresponding author)

${ }^{2}$ Nebojša Lukić, PhD prof., University of Kragujevac, Faculty of Engineering, Sestre Janjić 6, 34000 Kragujevac, lukic@kg.ac.rs

${ }^{3}$ Nikola Milutinović, MSc Student, University of Kragujevac, Faculty of Engineering, Sestre Janjić 6, 34000 Kragujevac, nikola.milutinovic95@gmail.com

${ }^{4}$ Aleksandar Nešović, PhD Student, University of Kragujevac, Faculty of Engineering, Sestre Janjić 6, 34000 Kragujevac, aca.nesovic@gmail.com
} 


\section{PRELIMINARNA PROCENA PRIMENE KOGENERACIJE NA BAZI MOTORA SA UNUTRAŠNJIM SAGOREVANJEM U STAMBENOM SEKTORU U KLIMATSKIM USLOVIMA SRBIJE UZ POMOĆ PROGRAMA ZA SIMULACIJU PONAŠANJA ZGRADA}

REZIME: U ovom radu izvršena je procena energetskih i ekonomskih performansi primene kogenerativnog sistema na bazi motora SUS u stambenom sektoru u srpskim klimatskim uslovima korišćenjem softvera za simulaciju energetskog ponašanja zgrada. Performanse sistema baziranog na SUS motoru su upoređene sa performansama druga dva konvencionalna sistema za pripremu PTV: gasnim i električnim zagrejačem vode. Upoređujući SUS motor sa gasnim zagrejačem, period potreban za povraćaj investicionih troškova motora relativno je visok (11,7 godina). Glavne prepreke za širu primenu kogenerativnog sistema SUS motora odnose se na visoke kapitalne troškove motora SUS i nisku cenu otkupljene ili prodate električne energije. U tom pogledu, neophodno je postići smanjenje investicionih troškova kogenerativnih sistema malih snaga. U odnosu na trenutnu vrednost u Srbiji, vrednost cene otkupljene i prodate električne energije (feed-in tarife) treba da se poveća za $37,5 \%$ odnosno $67,5 \%$, respektivno, kako bi se dostigla vrednost perioda otplate od pet godina. Upoređujući sistem baziran na SUS motoru sa električnim zagrejačem vode, primena SUS motora ekonomski je isplativa obzirom da period povraćaja investicije iznosi 3,42 godine. Prema rezultatima simulacije, kogenerativni sistem SUS motora obezbeđuje uštedu primarne energije od $28,81 \%$.

KLJUČNE REČI: kogeneracija, motor sa unutrašnjim sagorevanjem, primarna ušteda energije, dinamička simulacija 


\title{
A PRELIMINARY ASSESSMENT OF RESIDENTIAL APPLICATION OF INTERNAL COMBUSTION ENGINE BASED COGENERATION IN SERBIAN CLIMATIC CONDITIONS WITH BUILDING SIMULATION PROGRAM
}

\author{
Novak Nikolić, Nebojša Lukić, Nikola Milutinović, Aleksandar Nešović
}

\section{INTRODUCTION}

Cogeneration (CHP) represents the process of simultaneous or combined production of electrical (or mechanical) and thermal energy using a single primary energy source (fuel) within an integrated system. The main reasons for the application of the concept of cogeneration are reflected in the significantly higher efficiency of transformation and use of primary energy. In other words, cogeneration plants, in relation to separate electricity and thermal generation plants, contribute to higher primary energy savings, higher economic savings and reduction of greenhouse gas (GHG) emissions. The main components of the CHP plants are prime mover (heat engine), generator and heat recovery (heat exchanger). The CHP plants are categorized according to the type of prime mover which can be as: internal combustion engine (IC engine); gas turbine; steam turbine and fuel cell. The IC engine as the main part of the cogeneration system provides mechanical energy which is transformed into electrical energy as well as thermal energy by recovering heat from hot exhaust gases, water cooling system and lube oil system. Reciprocating IC engines used for residential cogeneration applications of less than $30 \mathrm{~kW}$ are frequently based on spark ignition engines that are mostly run on natural gas [1]. In relation to the other prime movers, the IC engines offer easy and fast start up, significant low and medium temperature heat recovery and occupy a small area in relation to the installed capacity.

Small scale residential cogeneration systems have been studied by many researchers on experimental and simulation basis. Aussant et al. [2] modelled and simulated two IC engine cogeneration units $\left(1 \mathrm{~kW}_{\mathrm{el}}\right.$ and $\left.2 \mathrm{~kW}_{\mathrm{el}}\right)$ providing thermal and electric energy to a Canadian residential houses. The results have shown that the CHP efficiency of the $1 \mathrm{~kW}_{\mathrm{el}}$ system was found to be higher than the $2 \mathrm{~kW}_{\mathrm{el}}$ system. They have found a net reduction of GHG emissions of approximately 20\%. Gonçalves et al. [3] experimentally tested $6 \mathrm{~kW}_{\text {el }}$ IC cogeneration unit and evaluated its energy and exergy performance considering different Italian and Portuguese heat and electricity scenarios. The obtained primary energy saving was equal to $3 \%$ for Portugal, and $10 \%$ for Italy, respectively. Dorer and Weber [4] compared different CHP technologies (prime movers) integrated in single and multi-family houses of different energy standard levels. The simulations results obtained by using the simulation program TRNSYS indicate that most CHP systems offered reductions (up to $34 \%$ ) in comparison with the gas boiler reference system and crediting the electricity exported to the grid. In Ref. [5] the CHP systems based on different prime movers $\left(1 \mathrm{~kW}_{\mathrm{el}}\right.$ to $9 \mathrm{~kW}_{\mathrm{el}}$ ) were experimentally tested in residential application in Italy and Germany. According to the results a significant primary energy savings amount up to $27 \%$ and $36 \%$, and a pollutant emissions reduction up to $33 \%$ and $35 \%$, in Italy and Germany, respectively. Ciampi et al. [6] performed energy, environmental and economic dynamic simulations of a residential micro-cogeneration system of $6 \mathrm{~kW}_{\mathrm{el}}$ in various Italian climatic zones. The best system performance was achieved for the coldest Italian city (Milan) for which the primary energy saving of $6.5 \%$, a reduction of $\mathrm{CO}_{2}$ equivalent emissions and operating costs of $12.8 \%$ and $29.9 \%$, respectively, were ensured. Marrasso et al. [7] analyzed natural gas IC based cogeneration system $\left(5.5 \mathrm{~kW}_{\mathrm{el}}\right)$ on experimental and simulation basis. The system ensured a primary energy saving of $12.1 \%$ and a reduction of equivalent $\mathrm{CO}_{2}$ emissions 
equal to $27.8 \%$. The payback period of the analyzed solution used to meet the electric and thermal demand of two residential buildings located in northern Spain, was equal to 11.9 years. Asaee et al. [8] conducted a preliminary techno-economic evaluation of retrofitting reciprocating IC engine based cogeneration into existing houses in five major climatic conditions of Canada for the purpose of achieving or approaching net-zero energy rating. In Ref. [9] the same authors performed a comprehensive techno-economic evaluation of retrofitting IC engine based cogeneration systems $\left(3.87 \mathrm{~kW}_{\mathrm{el}}\right.$ to $\left.25 \mathrm{~kW}_{\mathrm{el}}\right)$ in the Canadian housing stock. The simulation results show that cogeneration retrofit yields $13 \%$ energy savings while the total GHG emissions would be reduced by $35 \%$. Arbabi et al. [10] developed a numerical model to design and select a CHP unit based on an internal combustion engine. They concluded that several smaller engines in parallel mode is preferred over a single large engine due to longer operation period at full load operation and reliability level improvement.

Unfortunately there are practically no publications related to the techno-economic evaluation of IC based cogeneration systems in the Serbian climatic conditions using building energy simulation software. Using the model of residential building and the software EnergyPlus, the energetic and economical performance of IC based small scale cogeneration unit will be simulated and compared with performance of conventional systems. The purpose of this investigation is to gain a preliminary understanding of IC engine based cogeneration unit performance for the Serbian residential buildings and to identify the possible barriers for its widespread application. It is expected that this investigation will be very beneficial to those dealing with the design, analysis, simulation and energy performance assessment of IC engine cogeneration systems.

\section{BUILDING MODEL}

The selected building is a three-level student dormitory (Fig. 1). There are a total of twenty three bedrooms arranged on second and third level (Table 1). The dormitory provides accommodation and meals for students, as well as washing and drying services. A restaurant, kitchen, washing and drying service are located on the first level of the building. Restaurant services can also be used by those who are not accommodated in the dormitory.

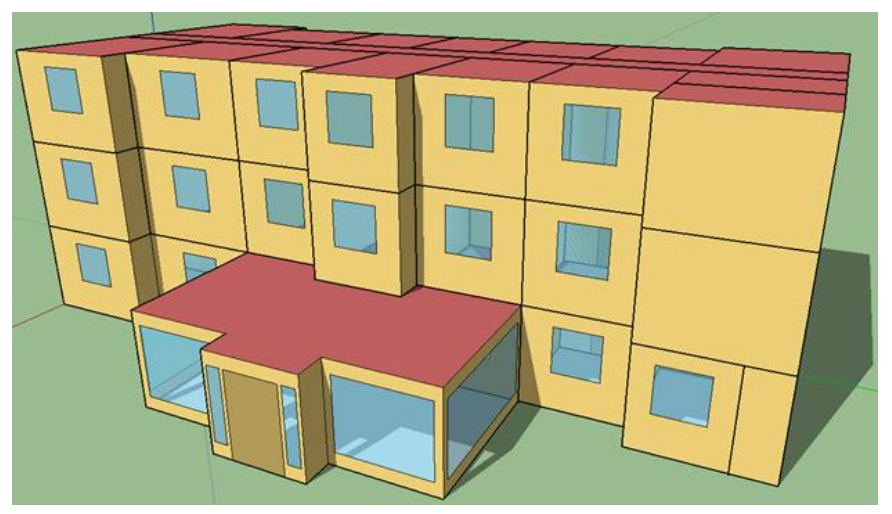

Figure 1. Isometric view of the analyzed student dormitory

The energy behaviour of the dormitory was simulated by using the EnergyPlus software (version 8.4.0) [11]. The EnergyPlus software takes into account all factors that influence 
A preliminary assessment of residential application of internal combustion engine based cogeneration in serbian climatic conditions with building simulation program

heat losses and loads in the building, such as electrical appliances, lighting, people occupancy, solar radiation, wind, infiltration and shading [12, 13]. The simulation was conducted for real weather data for the city of Kragujevac (Serbia). The people occupancy for bedrooms, toilets, bathrooms and restaurant is given in Table 1. The detailed yearly occupancy patterns (schedules) include people occupancy in the dormitory during the weeks (days) of lectures at faculties, the occupancy during the weeks of vacation, as well as the student occupancy in the dormitory during National holidays of the Republic of Serbia for 2017 [14]. It was assumed that the heat gain per person amounts $99 \mathrm{~W}$, which is related to the activity of reading (seated) [15]. The occupancy schedules were defined according to the activities and behaviour of the students from nearby faculties, who are accommodated in the selected dormitory. The operation schedules for lighting correspond to the people occupancy schedules, with the difference when the lights are turned off during sleep and when the level of daylight is satisfactory.

Table 1. People occupancy and electric load in the dormitory rooms and restaurant

\begin{tabular}{|c|c|c|c|}
\hline $\begin{array}{c}\text { Room } \\
\text { (total number) }\end{array}$ & $\begin{array}{c}\text { Maximum people } \\
\text { occupancy } \\
(-)\end{array}$ & $\begin{array}{c}\text { Power of } \\
\text { lights } \\
(\mathrm{W})\end{array}$ & $\begin{array}{c}\text { Power of } \\
\text { electrical appliances } \\
(\mathrm{W})\end{array}$ \\
\hline One bed room (2) & 1 & 23 & 90 \\
\hline Three bed room (11) & 3 & 27 & 270 \\
\hline Four bed room (10) & 4 & 36 & 360 \\
\hline Bathroom (2) & 4 & 18 & - \\
\hline Toilet (2) & 4 & 18 & - \\
\hline Restaurant (1) & 123 & 81 & - \\
\hline
\end{tabular}

The highest electricity consumption within a dormitory is related to the electrical appliances located in kitchen. In order to simulate real operation of these appliances the electricity consumption data collected from fourteen UK public commercial kitchens were used [16]. All electricity consumption data for kitchens has been gathered exclusively from all cooking and food storage appliances, omitting any kitchen ventilation, washing or gas consuming appliances (Table 2).

Table 2. Average total daily electricity consumption for cooking, food storage, washing and drying appliances

\begin{tabular}{|c|c|c|c|c|}
\hline & $\begin{array}{c}\text { Walk in Fridges } \\
{[16]}\end{array}$ & $\begin{array}{c}\text { Walk in } \\
\text { Freezers [16] }\end{array}$ & $\begin{array}{c}\text { Other cooking } \\
\text { appliances [16] }\end{array}$ & $\begin{array}{c}\text { Combi-Ovens } \\
{[16]}\end{array}$ \\
\hline $\begin{array}{c}\text { El. consu. } \\
(\mathrm{kWh})\end{array}$ & 13.81 & 39.17 & 6.08 & 35.71 \\
\hline $\begin{array}{c}\text { Other } \\
\text { Refrigeration [16] }\end{array}$ & $\begin{array}{c}\text { Clothes washers } \\
{[17]}\end{array}$ & $\begin{array}{c}\text { Clothes dryers } \\
{[18]}\end{array}$ & $\begin{array}{c}\text { Dishwashers } \\
{[19]}\end{array}$ \\
\hline $\begin{array}{c}\text { El. consu. } \\
(\mathrm{kWh})\end{array}$ & 70.13 & 6 & 13.76 & 12.96 \\
\hline
\end{tabular}

The values for electricity consumption for washing and drying appliances were taken from product catalogs. Four clothes washers and four dryers provide washing and drying of bed 
sheets, while four dishwashers were used for dishwashing. It should be mentioned that electricity data given in Table 2 are related to the maximum people occupancy in the student dormitory. In other words, electricity consumption of cooking, food storage, washing and drying appliances correspond to the people occupancy.

\section{DHW LOAD PROFILE}

The shape and magnitude of DHW load of a student dormitory largely depends on number of students, their activity, time of day and time of year. Due to the absence of real load profile the DHW load profiles were determined according to the recommendations given in [20] and in Table 3. The total DHW consumption of dormitory represents the sum of consumption for all places (units) of consumption: bathrooms, restaurant, kitchen and laundry room. Both bathrooms are equipped with four showers and four wash basins. The hot water is used for maintaining personal hygiene (hand washing, showering, teeth brushing,..). It was assumed that half of the students take a shower in the morning and the other half in the evening. The adopted consumption of hot water with the desired temperature in bathrooms is given in Table 3. The only place in the restaurant where hot water is consumed is two wash basins (Table 3). They are used for hand washing before and after a meal. The maximum number of people that can use restaurant services in the same time is 123 , of which 77 are students accommodated in the dormitory. The hot water consumption in the restaurant occurs three times a day, during breakfast, lunch and dinner.

The DHW consumption profile in the kitchen is more complex than the previously described profiles. In the kitchen, the consumption of DHW is related to the preparation of meals, hot drinks and dishwashing (Table 3). The highest consumption occurs during the lunch preparation and the least during the breakfast preparation.

The laundry service implies clothes and bed sheets washing for students accommodated in the selected dormitory (Table 3). The laundry room includes four washing machines, two of which are for clothes washing and the other two for bad sheets washing. The washing process performs twice during the evening.

Table 3. DHW consumption characteristics

\begin{tabular}{|c|c|c|c|c|}
\hline \multicolumn{2}{|c|}{ Place of consumption } & $\begin{array}{l}\text { DHW consumption } \\
\text { per person }\end{array}$ & Duration & $\begin{array}{c}\text { Desired } \\
\text { temperature }\end{array}$ \\
\hline \multirow{2}{*}{ Bathrooms } & Wash basin & 10 & 2 & 40 \\
\hline & Shower & 50 & 6 & 40 \\
\hline Restaurant & Wash basin & 5 & 1.5 & 40 \\
\hline \multirow{4}{*}{ Kitchen } & Meal preparation & 1 & 10 & 60 \\
\hline & Hot drink preparation & 0.3 & 10 & 60 \\
\hline & Dishwashers & 40 (1/washing) & 30 & 60 \\
\hline & Wash basins & 30 (1/washing) & 10 & 60 \\
\hline $\begin{array}{l}\text { Laundry } \\
\text { room }\end{array}$ & Washing machines & 188 (1/washing) & 30 & 40 \\
\hline
\end{tabular}


A preliminary assessment of residential application of internal combustion engine based cogeneration in serbian climatic conditions with building simulation program

\section{PLANT MODEL}

Three different systems (cases) for DHW preparation were investigated (Fig. 2). The first case (System 1) is related to the internal combustion engine based cogeneration system with auxilary gas heater. The system with natural gas water heater represents the case 2 (System 2 ) and the system with electric water heater represents the case 3 (System 3). The only difference between the System 2 and 3 is in type of fuel used for DHW heating.

For the System 1 the thermal energy for DHW preparation is provided from lube oil system, jacket water cooling system and exhaust gas system. The water from the water storage tank (water heater) flows through the lube oil, jacket water and exhaust gas heat exchanger where it is heated. The heated water then circulates through the heat exchanger of the water storage tank where it transfers the heat to the water for DHW purposes. If the waste heat from engine systems is not enough to balance the DHW thermal load, auxiliary gas heater, within the storage tank, is turned on. When there is excess heat generated an excess heat exchanger is used to transfer engine heat to a surrounding.

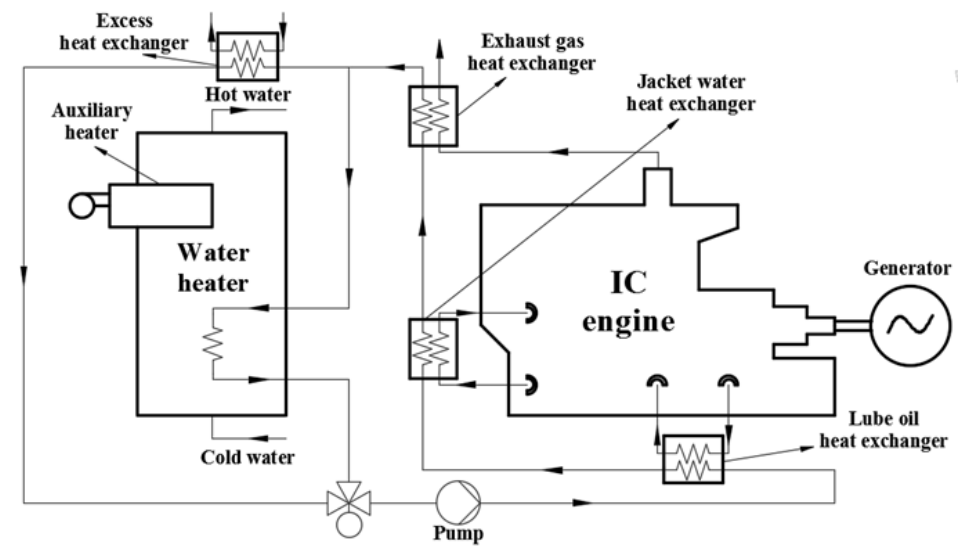

Figure 2. Internal combustion engine based cogeneration system (System 1)

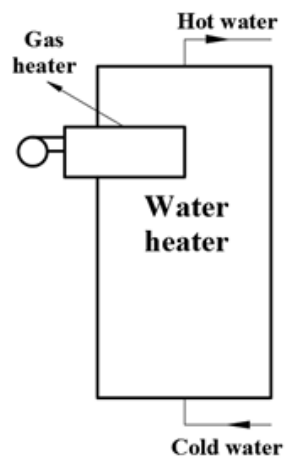

a)

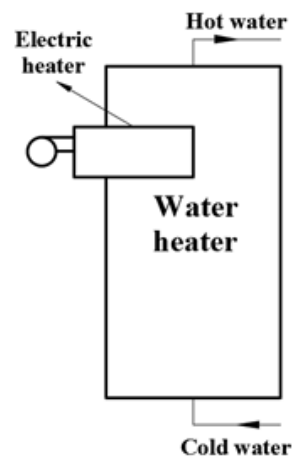

b)

Figure 3. Conventional water heaters: a) gas water heater (System 2) and b) electric water heater (System 3) 
The heat capacity $(170 \mathrm{~kW})$ and volume of the water heater $(3200 \mathrm{l})$ are determined according to the DHW load profile and procedure described in [20]. The adopted values of the parameters needed for sizing of the water heater are given in Table 4.

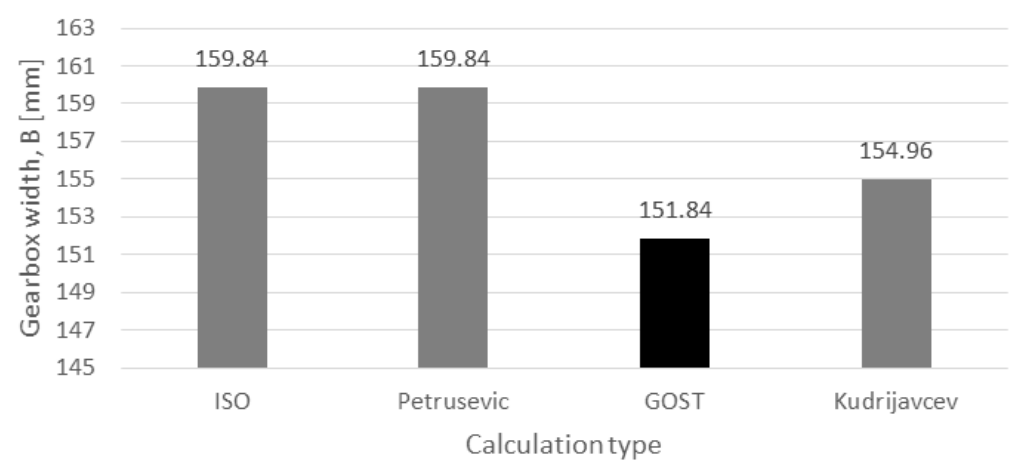

Figure 3. Gearbox widths

According to height criteria values corresponding to each design solution are given in Figure 4. The range of values is from 252.6 (Petrusevic) to $350 \mathrm{~mm}$ (Kudrijavcev). According to this criteria the most favourable solution is according to Petrusevic.

Table 4. The sizing parameters of the water heater

\begin{tabular}{|c|c|c|}
\hline Parameter & Unit & Value \\
\hline Maximum flow rate of the DHW during one hour & $(\mathrm{l} / \mathrm{s})$ & 0.961 \\
\hline Minimum allowed temperature for water in water heater & $\left({ }^{\circ} \mathrm{C}\right)$ & 10 \\
\hline Heat loss coefficient of the water heater & - & 1.1 \\
\hline Thermal efficiency of the electric/natural gas heater & - & 0.9 \\
\hline Number of hours for water heating & $(\mathrm{h})$ & 1 \\
\hline Number of hours for water heater operation & $(\mathrm{h})$ & 2 \\
\hline Maximum temperature for water in water heater & $\left({ }^{\circ} \mathrm{C}\right)$ & 60 \\
\hline Factor due to unused space under the heating surface of the water heater & - & 1.1 \\
\hline
\end{tabular}

In order to determine the size of the cogeneration system it is necessary to know the daily, monthly or yearly profile of heat and electrical demands. For the selected student dormitory the IC cogeneration system is sized to provide minimum (base) thermal energy requirement for DHW preparation. In Fig. 4 the daily profile of heater heat capacity for the day of maximum heat demand is shown. 
A preliminary assessment of residential application of internal combustion engine based cogeneration in serbian climatic conditions with building simulation program

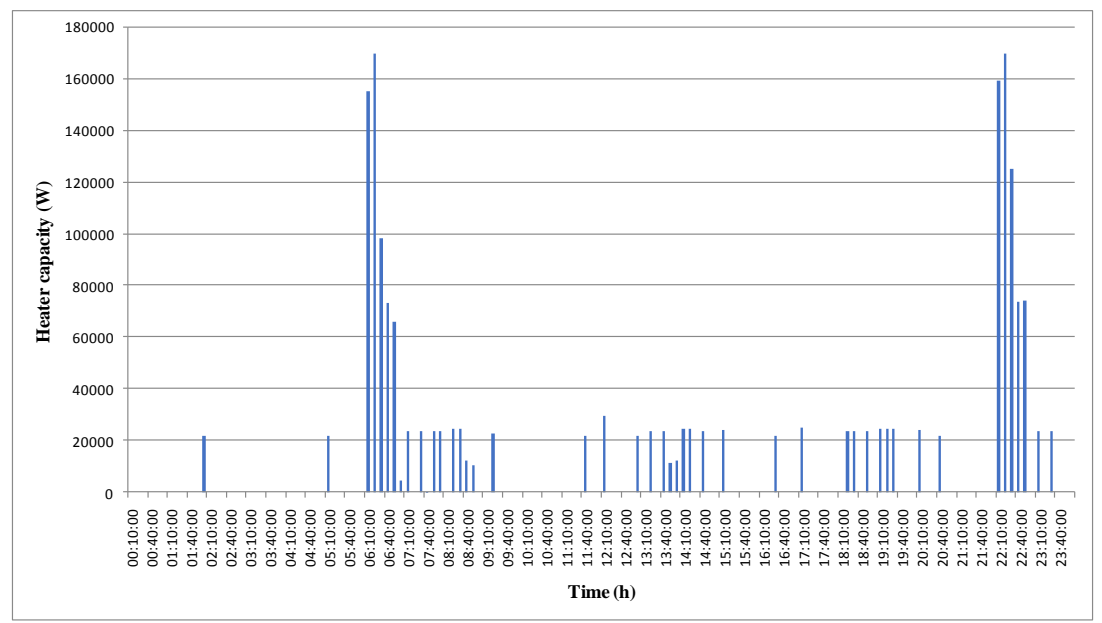

Figure 4. The daily profile of heat demands for DHW preparation

According to the data from Fig. 4 the daily share of heater heat capacity up to $25 \mathrm{~kW}$ amounts $76 \%$, and over $25 \mathrm{~kW}$ amounts $24 \%$. Based on this conclusion, the commercially available IC cogeneration unit, Viessmann Vitobloc 200 EM-9/20, has been adopted. Its technical characteristics are given in Table 5.

Table 5. Technical characteristics of the IC cogeneration unit Viessmann Vitobloc 200 EM$9 / 20[21]$

\begin{tabular}{|c|c|c|c|}
\hline Load $(\%)$ & 50 & 75 & 100 \\
\hline Electrical output $(\mathrm{kW})$ & 4.3 & 6.4 & 8.5 \\
\hline Thermal output $(\mathrm{kW})$ & 12.3 & 16.1 & 20.1 \\
\hline Fuel (natural gas) use $(\mathrm{kW})$ & 18.3 & 23.8 & 30.1 \\
\hline Electrical efficiency $(\%)$ & 23.5 & 26.9 & 28.2 \\
\hline Thermal efficiency $(\%)$ & 67.2 & 67.6 & 66.8 \\
\hline Maximum water temperature for heat recovery $\left({ }^{\circ} \mathrm{C}\right)$ & & 65 \\
\hline Maximum exhaust gas temperature $\left({ }^{\circ} \mathrm{C}\right)$ & \multicolumn{3}{|l}{} \\
\hline
\end{tabular}

The IC engine operates at full load at all times during the period from 6 a.m. to 11 p.m., to maintain the thermal storage tank water temperature of $60{ }^{\circ} \mathrm{C}$. During the weeks of vacation and National holidays the cogeneration unit does not operate. The effect of engine start-up and shut-down losses are ignored in the simulations.

In order to simulate the energy behavior of the IC cogeneration system the empirical mathematical model available in the software EnergyPlus was used. The model which simulates the operation of a modified Otto engine, consists of performance curves which has to be generated by fitting catalog data to second order polynomial equations. Five performance curves were used: "shaft power" curve; "jacket heat recovery" curve; "lube heat recovery" curve; "total exhaust energy" curve and "exhaust temperature" curve. 
The "shaft power" curve is a equation that is used to calculate the electrical output divided by the fuel energy input as a function of part load ratio:

$$
\frac{E_{\mathrm{C}}}{F_{\mathrm{C}}}=\frac{E_{\mathrm{C}}}{m_{\text {fuel }} \cdot L H V}=a_{1}+a_{2} \cdot P L R+a_{3} \cdot P L R^{2}
$$

where $E_{\mathrm{C}}$ is the engine electrical output $(\mathrm{W}) ; F_{\mathrm{C}}$ is the fuel used by engine $(\mathrm{W}) ; \dot{m}_{\text {fuel }}$ is the fuel mass flow rate $(\mathrm{kg} / \mathrm{s}) ; L H V$ is the lower heating value of a fuel $(\mathrm{J} / \mathrm{kg}) ; a_{1}, a_{2}, a_{3}$ are coefficients (-) $\left(a_{1}=0.004 ; a_{2}=0.644 ; a_{3}=-0.371\right) ; P L R$ is the part load ratio of a engine (-) $\left(P L R=E_{\mathrm{C}} / N E_{\mathrm{C}}\right.$, where $N E_{\mathrm{C}}$ is the rated electrical output of a engine $\left.(\mathrm{W})\right)$.

The "jacket heat recovery" and "lube heat recovery" curves are a quadratic equations that determine the amount of recovered jacket heat and recovered lube oil heat, respectively, as a function of part load ratio:

$$
\begin{gathered}
\frac{H_{\mathrm{W}}}{F_{\mathrm{C}}}=\frac{H_{\mathrm{W}}}{m_{\text {fuel }} \cdot L H V}=b_{1}+b_{2} \cdot P L R+b_{3} \cdot P L R^{2} \\
\frac{H_{\mathrm{L}}}{F_{\mathrm{C}}}=\frac{H_{\mathrm{L}}}{m_{\text {fuel }} \cdot L H V}=c_{1}+c_{2} \cdot P L R+c_{3} \cdot P L R^{2}
\end{gathered}
$$

where $H_{\mathrm{W}}$ is the heat recovered from the jacket water cooling system (W); $b_{1}, b_{2}, b_{3}$ are coefficients (-) $\left(b_{1}=0.2866 ; b_{2}=0 ; b_{3}=0\right) ; H_{\mathrm{L}}$ is the heat recovered from the lube oil system $(\mathrm{W})$ and $c_{1}, c_{2}, c_{3}$ are coefficients $(-)\left(c_{1}=0.1719 ; c_{2}=0 ; c_{3}=0\right)$.

The amount of heat recovered by the exhaust gas heat exchanger is defined by the "total exhaust energy" and "exhaust temperature" curves. The exhaust gas temperature and flow rate are used if a stack heat exchanger is used to recover waste heat from the engine exhaust gas. This temperature is the inlet temperature to the heat exchanger. Both quadratic equations are in a function of part load ratio:

$$
\begin{gathered}
\frac{H_{\mathrm{EXH}}}{F_{\mathrm{C}}}=\frac{H_{\mathrm{EXH}}}{m_{\text {fuel }} \cdot L H V}=d_{1}+d_{2} \cdot P L R+d_{3} \cdot P L R^{2} \\
\frac{T_{\mathrm{EXH}}}{F_{\mathrm{C}}}=\frac{T_{\mathrm{EXH}}}{m_{\text {fuel }} \cdot L H V}=e_{1}+e_{2} \cdot P L R+e_{3} \cdot P L R^{2}
\end{gathered}
$$

where $H_{\mathrm{EXH}}$ is the heat recovered from the exhaust gas system (W); $d_{1}, d_{2}, d_{3}$ are coefficients $(-)\left(d_{1}=0.1965 ; d_{2}=0 ; d_{3}=0\right) ; \mathrm{T}_{\mathrm{EXH}}$ is the exhaust gas temperature $(\mathrm{K})$ and $e_{1}, e_{2}, e_{3}$ are coefficients $\left(e_{1}=373 ; e_{2}=0 ; e_{3}=0\right)$.

The coefficients $a_{1}, a_{2}, a_{3}, b_{1}, b_{2}, b_{3}, c_{1}, c_{2}, c_{3}, d_{1}, d_{2}, d_{3}, e_{1}, e_{2}$ and $e_{3}$ were generated according to the catalog data of the selected IC cogeneration unit [21]. It should be noted that for lower difference between the temperature of water leaving the exhaust heat exchanger and the temperature of water in water heater heat recovery amount will be lower. In that case the excess heat exchanger is activated in order to transfer the excess heat to a surrounding. 
A preliminary assessment of residential application of internal combustion engine based cogeneration in serbian climatic conditions with building simulation program

\section{SIMULATION RESULTS AND ANALYSIS}

\section{1 Energy amounts}

Annual simulations of operation of all three investigated systems for DHW preparation were performed. The results of simulations were used to compare the performance of the IC cogeneration system (System 1) with conventional systems (System 2 and System 3). Fig. 5 presents the monthly energy consumption for DHW preparation of the analyzed systems. The energy consumption of the System 1 includes the gas consumption of IC engine and gas consumption of auxiliary heater (burner).

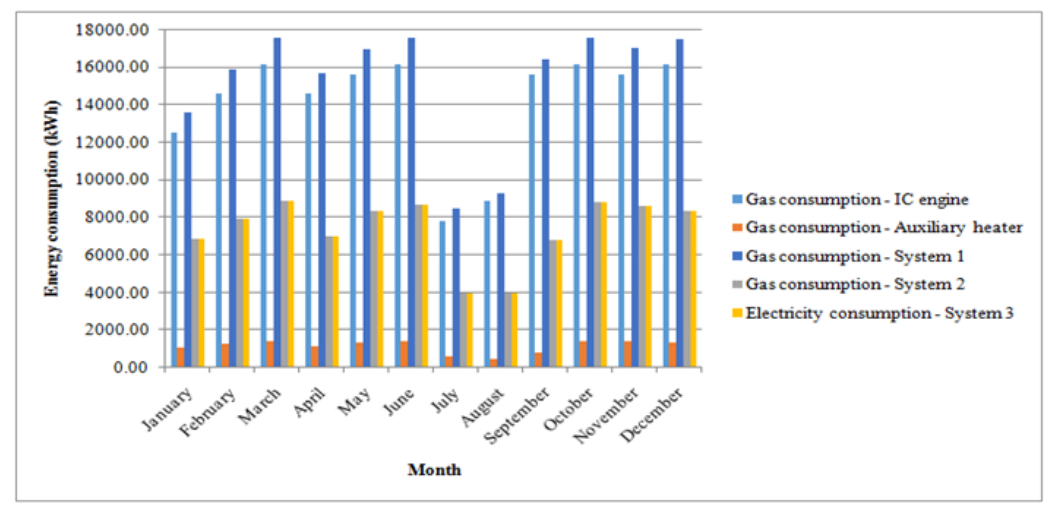

Figure 5. The monthly energy consumption for DHW preparation of the investigated systems: IC cogeneration system (System 1); Gas water heater (System 2); Electric water heater (System 3)

The energy consumption varies during the year, being different each month as a consequence of the people occupancy variation. In this respect, the highest energy consumption corresponds to the maximum people occupancy in the student dormitory, during March, June, October and December. On the other side, the minimum DHW loads and energy consumption were recorded during the weeks of vacation (July and August). It should be noted that the energy consumption for the gas and electric water heater (System 2 and System 3) is the same because the values of their thermal efficiency are equal (Table 4). Since, the IC cogeneration unit is dimensioned to cover the base thermal load the auxiliary burner provides additional thermal energy. The total yearly gas consumption of the IC engine amounts $170061.37 \mathrm{kWh}$ while the consumption of the gas burner amounts 13526.75 $\mathrm{kWh}$ which represents $7.95 \%$ of the engine gas consumption. The yearly consumption of the System 2 and 3 is equal to $88234.44 \mathrm{kWh}$.

The monthly amounts of heat recovered by the lube oil, jacket water and exhaust gas heat exchangers are shown in Fig. 6. The total heat recovered from the IC cogeneration unit is $73665.52 \mathrm{kWh}$. The largest share of recovered heat of $47.3 \%$ is related to the jacket water, followed by share of $28.4 \%$ for lube oil and $24.3 \%$ for exhaust gas. As it was mentioned the amount of recovered heat is affected by the DHW needs and accordingly the temperature of the water inside the thermal storage tank. 


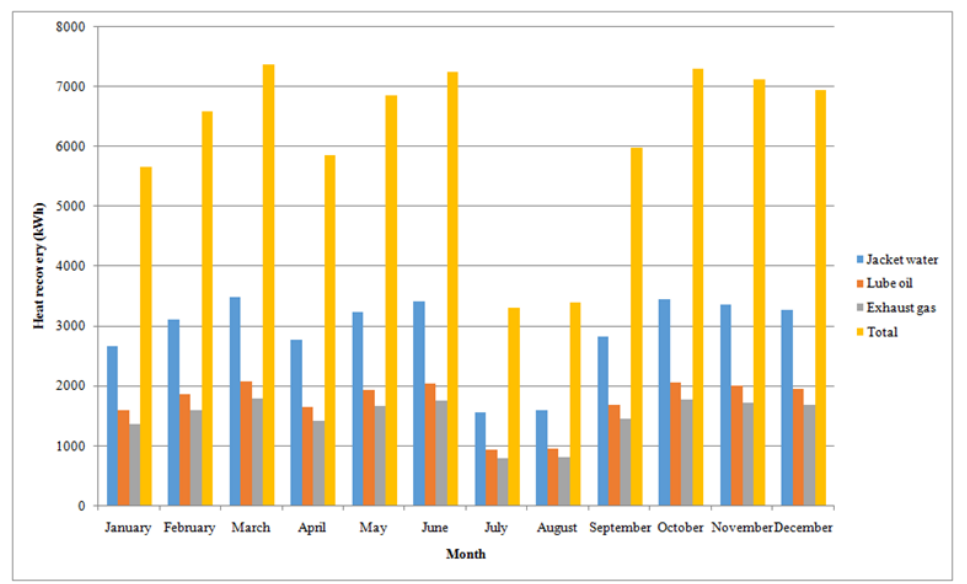

Figure 6. The monthly values of heat recovered from lube oil, jacket water and exhaust gas of IC cogeneration system

Fig. 7 presents the monthly electricity consumption and electricity production within the investigated student dormitory. The electricity is consumed by lighting and electrical appliances of the bedrooms, bathrooms, restaurant, kitchen, laundry and machine room. Due to the use of LED lights the electricity consumption for lighting is very low and almost negligible in relation to the consumption for electrical appliances. The amount of electricity consumption for electrical appliances is largely affected by the electric load and power of appliances located in the kitchen. The annual electricity consumption for lighting, appliances and entire student dormitory is $1126.24 \mathrm{kWh}, 63546.95 \mathrm{kWh}$ and $64673.19 \mathrm{kWh}$, respectively.

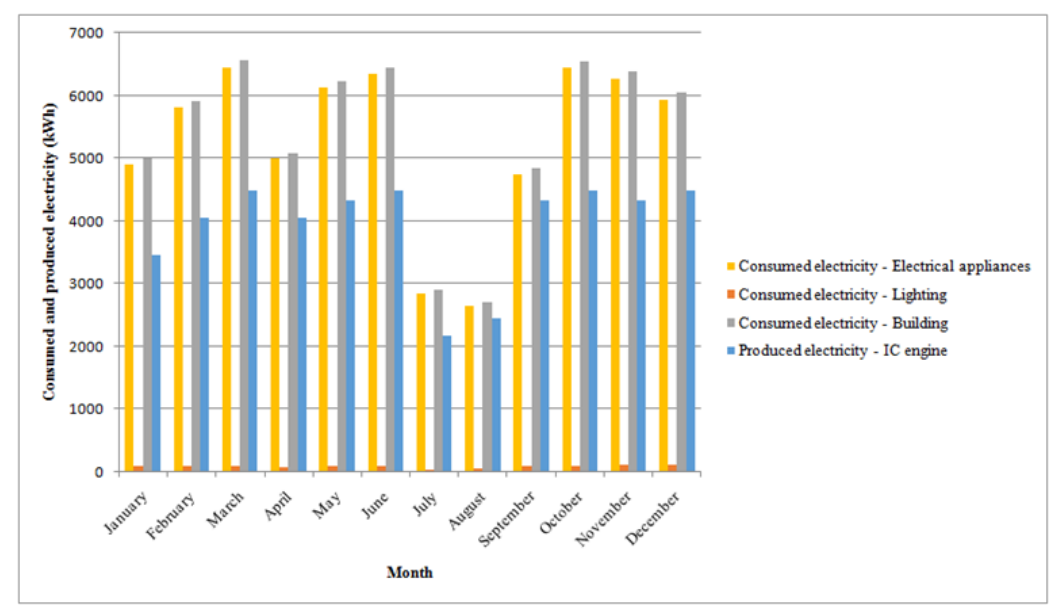

Figure 7. The monthly values of consumed and produced electricity within the student dormitory

The IC cogeneration system is in operation at full electrical load at all times during the period from 6 a.m. to 11 p.m. In this respect, the amount of electricity produced by the IC engine is the same for every day of its operation. The value of annual electricity production 
A preliminary assessment of residential application of internal combustion engine based cogeneration in serbian climatic conditions with building simulation program

of $47107 \mathrm{kWh}$ covers $72.84 \%$ of the annual electricity consumption of the student dormitory. The highest cover (90\%) is reached in August and September due to the significantly lower electricity consumption caused by lower people occupancy in the dormitory. According to the simulation results, the thermal and electrical efficiency of the simulated IC cogeneration system amounts 0.433 and 0.277 , respectively. For the adopted and assumed value for the thermal and electrical efficiency of separate heat and electricity production of 0.9 and 0.3 , respectively, the primary energy savings ratio $(P E S R)$ is equal to $28.81 \%$ while the total efficiency of the cogeneration unit is 0.71 .

\subsection{Energy costs}

The costs of fuel consumption for investigated systems for DHW preparation has to be determined in order to analyze the economic feasibility of IC cogeneration system application. For the System 1 the costs are defined by summing the total fuel consumption of the IC engine unit and the fuel consumption of the auxiliary heater. Since the System 1 and System 2 use natural gas as fuel the fuel costs are calculated by dividing the fuel consumption by LHV of natural gas of $38.23 \mathrm{MJ} / \mathrm{m}^{3}$ and then multiplying the consumption in cubic meters by the price of natural gas of $32.28 \mathrm{RSD} / \mathrm{m}^{3}(1 €=118.5 \mathrm{RSD})$.

The costs for electricity consumed by the System 3, lighting and electrical appliances are calculated by multiplying the amount of consumed electricity by the price of electricity which is defined according to the tariff payment system given in Table 6 . The shown value of the electricity price does not include the taxes and levies.

Table 6. Tariff payment system for consumed electricity in Serbia (for two tariff electricity meter) [22]

\begin{tabular}{|c|c|c|}
\hline Households & $\begin{array}{c}\text { Higher daily tariff } \\
(\mathrm{RSD} / \mathrm{kWh})\end{array}$ & $\begin{array}{c}\text { Lower daily tariff } \\
(\mathrm{RSD} / \mathrm{kWh})\end{array}$ \\
\hline Green zone: 0 - $350 \mathrm{kWh}$ & 5.962 & 1.491 \\
\hline Blue zone: $350-1600 \mathrm{kWh}$ & 8.943 & 2.236 \\
\hline Red zone: over $1600 \mathrm{kWh}$ & 17.887 & 4.472 \\
\hline
\end{tabular}

The tariff system consists of two tariff categories: higher daily tariff and lower daily or nightly tariff. The amounts of electricity consumed in both tariff categories are determined on the basis of operation schedules of DHW systems and electric equipment. For the operation of the System 1 and System 2 it was adopted that $85 \%$ of electricity is consumed during the duration of the higher tariff and $15 \%$ during the duration of the lower tariff category. On the other hand, when the System 3 is in operation the electricity is the only form of energy used in the student dormitory. Thus, the shares of consumed electricity are different and amount $60 \%$ (higher tariff) and $40 \%$ (lower tariff).

The easiest and the most commonly used economic indicator for analyzing financial attractiveness of a cogeneration project is the simple payback period $(S P B=F / S)$. It presents the length of time $(S P B)$, expressed in years, required to return investment costs $(F)$. The parameter $S$ denotes the annual net savings. According to the electrical output of the selected IC engine $(8.5 \mathrm{~kW})$ and estimated capital costs for IC cogeneration systems of various sizes, given in Table 7, the value for investment costs of $2800 \$ / \mathrm{kW}_{\mathrm{el}}$ was adopted. 
Table 7. Estimated capital costs for IC cogeneration systems [1]

\begin{tabular}{|c|c|c|c|c|c|}
\hline Cost Component & Senertec & \multicolumn{2}{|c|}{ North American Cogeneration Systems } & MAN \\
\hline Electrical Capacity $(\mathrm{kW})$ & 5.5 & $7.1-10.7$ & $20.1-23.3$ & $30.3-35.0$ & 100.0 \\
\hline Electrical Efficiency $(\%)$ & 27 & 28.1 & 37.4 & 33.1 & 30.6 \\
\hline Thermal Efficiency $(\%)$ & 61 & 56.5 & 50.0 & 51.2 & 50.4 \\
\hline Installed Cost $\left(\$ / \mathrm{kW}_{\mathrm{el}}\right)$ & 3020 & 2800 & 1600 & 1300 & 1080 \\
\hline
\end{tabular}

The maintenance costs of the IC engine affect the value of the annual net savings $S$. These costs are related to the repair or replacement of engine components such as oil and air filters, spark plugs, gaskets, valves, piston rings and oil. They have been estimated to be 0.0105 $\$ / \mathrm{kWhe}[1]$.

The investment costs, annual fuel consumption (operating costs), maintenance costs and the annual savings for investigated cogeneration system for DHW preparation are presented in Table 8. In the same table the operating and maintenance costs for the other two analyzed systems (System 2 and 3) are shown and compared with the same for the System 1.

Table 8. Economic analysis of the IC based cogeneration system

\begin{tabular}{|c|c|c|c|c|}
\hline & System 1 & System 2 & System 1 & System 3 \\
\hline Costs & \multicolumn{5}{|c|}{} \\
\hline Natural gas (RSD) & 558054.1 & 268206.8 & 558054.1 & - \\
\hline Electricity - electric heater (RSD) & - & - & - & 949516.95 \\
\hline Electricity - electric equipment (RSD) & 829814.7 & 829814.7 & 829814.7 & 654506.62 \\
\hline Investment (RSD) & 2451400 & - & 2451400 & - \\
\hline Operating and maintenance (RSD) & 50946.2 & - & 50946.2 & - \\
\hline Total annual costs (RSD) & 1438815.1 & 1098021.6 & 1438815.1 & 1604023.6 \\
\hline Savings & \multicolumn{5}{|c|}{3.42} \\
\hline Unconsumed electricity (RSD) & 550955.81 & 0 & 550955.81 & 0 \\
\hline Total annual savings (RSD) & 210162.34 & \multicolumn{2}{|c|}{716164.33} \\
\hline SPB (years) & \multicolumn{2}{|c|}{11.66} & \multicolumn{3}{|c|}{} \\
\hline
\end{tabular}

The $S P B$ of the IC engine was calculated under assumption that the System 2 or the System 3 have been already installed in the student dormitory. From the comparison of the System 1 and 2 it can be concluded that the payback period of 11.7 years is relatively high. Accordingly, the selected IC cogenerated system can be considered as economically unsustainable. The investment costs and the low price of purchased electricity were found to be the main obstacles to implement the IC based cogeneration system. The capital costs per unit capacity of a cogeneration plant increase as the size of the plant is decreased (Table 7). The costs of the selected IC engine $\left(8.5 \mathrm{~kW}_{\mathrm{el}}\right)$ are 2.6 times higher than the capital costs for the engine with capacity of $100 \mathrm{~kW}_{\mathrm{el}}$. In this respect, the investment cost reduction in small scale cogeneration systems has to be achieved.

On the basis of the values of energy consumption and energy costs of the analyzed student dormitory the average price for purchased electricity amounts $12.83 \mathrm{RSD} / \mathrm{kWh}(10.83$ $\mathrm{c} € / \mathrm{kWh}$ ). This electricity price does not support the application of IC based cogeneration plants. Comparing with the average electricity price in the European Union (for 28 
A preliminary assessment of residential application of internal combustion engine based cogeneration in serbian climatic conditions with building simulation program

countries) of $17.77 \mathrm{c} € / \mathrm{kWh}$ [23] and the average electricity price in Germany of 26.67 $\mathrm{c} € / \mathrm{kWh}[23]$ it is relatively low. According to these prices and the average price of natural gas in the European Union $(5.42 \mathrm{c} € / \mathrm{kWh})$ [24] and Germany $(5.44 \mathrm{c} € / \mathrm{kWh})$ [24] the payback period would be 7.46 and 2.98 years, respectively.

The return of investment can be reduced by incentives in the form of subsidies and by implementation of the clean development mechanism (certified emission reduction). In order to encourage investors and reduce the investment risk the Government of the Republic of Serbia has adopted feed-in tariffs for different types of power plants which have obtain the status of the privileged electric power producers. The feed-in tariff for the combined heat and power generation is $8.89 \mathrm{c} € / \mathrm{kWh}$ [25]. If all produced electricity within a dormitory would be sold to the local company for electricity distribution for the mentioned price of $10.53 \mathrm{RSD} / \mathrm{kWh}(8.89 \mathrm{c} € / \mathrm{kWh})$ the $S P B$ would be even higher, 15.8 years. This leads to the conclusion that the existing value of the feed-in tariff is also disincentive. In order to achieve the payback period of 5 years, the value of $17.64 \mathrm{RSD} / \mathrm{kWh}(14.89 \mathrm{c} € / \mathrm{kWh})$ for the price of sold electricity should be introduced. In other words, the average purchased electricity price has to be $37.5 \%$ higher while the feed-in tariff should be increased by $67.5 \%$.

On the other hand, comparing the System 1 with the System 3 the parameter SPB is relatively low (3.42 years) due to the significantly high costs for electricity used for heating DHW (949516.95 RSD) by using the System 3. Although, for this case the implementation of IC based cogeneration unit is justified the water heating systems equipped with conventional electric heater are undesirable in terms of energy utilization efficiency because the overall conversion efficiency into thermal energy is relatively low.

\section{CONCLUSIONS}

In this paper the energetic and economic performance assessment of residential application of IC engine based cogeneration system in the Serbian climatic conditions using building energy simulation software was performed. The investigated residential building is a student dormitory. The simulations performed for real weather data for the city of Kragujevac (Serbia) include detailed annual operation schedules for lighting, electrical appliances and annual occupancy and DHW load patterns. For the selected student dormitory the IC engine is sized to provide minimum thermal energy requirement for DHW preparation. The performance of IC based system was compared with the performance of the two other conventional systems for DHW preparation: gas water heater and electric water heater. Comparing the IC based system with gas water heater the period required to return investment costs of IC engine is relatively high (11.7 years). The main barriers for widespread residential application of IC engine cogeneration system are related to the high capital costs and low price of purchased or sold electricity. The reduction of investment costs, by introducing incentive measures in the form of non-refundable funds in the appropriate percentage value of the investment costs would certainly contribute to the reduction of the payback period value and support development of small scale cogeneration systems. In relation to the current price in Serbia the price of purchased and sold electricity (feed-in tariff) should be higher by $37.5 \%$ and $67.5 \%$, respectively, in order to achieve the value of payback period of five years. Comparing the IC based system with electric water heater the application of the IC based system is economically feasible since the payback period amounts 3.42 years. According to the simulation results, the IC engine cogeneration system ensured a primary energy saving of $28.81 \%$. It should be noted that economic analysis does not include the interest rate, time value of money, as well as maintenance costs for System 2 and 3 which would certainly affect the payback period. 


\section{ACKNOWLEDGMENTS}

This investigation is a part of the project TR 33015 of the Technological Development of the Republic of Serbia and project III 42006 of Integral and Interdisciplinary investigations of the Republic of Serbia. We would like to thank the Ministry of Education, Science and Technological Development of the Republic of Serbia for their financial support during this investigation.

\section{REFERENCES}

[1] Knight, I., Ugursal, V.I., "Residential cogeneration systems: a review of current technologies", A Report of Annex 42 of the International Energy Agency, Energy Conservation in Buildings and Community Systems Programme, 2005.

[2] Aussant, C.D., Fung, A.S., Ugursal, V.I., Taherian, H.: "Residential application of internal combustion engine based cogeneration in cold climate - Canada", Energy and Buildings, Vol. 41, No. 12, 2009, pp 1288-1298.

[3] Gonçalves, P., Angrisani, G., Roselli, C., Gaspar, A.R., Gameiro da Silva, M.: "Comparative energy and exergy performance assessments of a microcogenerator unit in different electricity mix scenarios", Energy Conversion and Management, Vol. 73, 2013, pp 195-206.

[4] Dorer, V., Weber, A.: "Energy and $\mathrm{CO}_{2}$ emissions performance assessment of residential micro-cogeneration systems with dynamic whole-building simulation programs", Energy Conversion and Management, Vol. 50, No. 3, 2009, pp 648-657.

[5] Roselli, C., Sasso, M., Sibilio, S., Tzscheutschler, P.: "Experimental analysis of microcogenerators based on different prime movers", Energy and Buildings, Vol. 43, No. 4, 2011, pp 796-804.

[6] Ciampi, G., Rosato, A., Scorpio, M., Sibilio, S.: "Energy, Environmental and Economic Dynamic Simulation of a Micro-Cogeneration System Serving an Italian Multi-Family House", Energy Procedia, Vol. 78, 2015, pp 1141-1146.

[7] Marrasso, E., Roselli, C., Sasso, M., Picallo-Perez, A., Sala Lizarraga, J.M.: "Dynamic simulation of a microcogeneration system in a Spanish cold climate", Energy Conversion and Management, Vol. 165, 2018, pp 206-218.

[8] Asaee, S.R., Ugursal, V.I., Beausoleil-Morrison, I.: "Techno-economic evaluation of internal combustion engine based cogeneration system retrofits in Canadian houses - A preliminary study", Applied Energy, Vol. 140, 2015, pp 171-183.

[9] Asaee, S.R., Ugursal, V.I., Beausoleil-Morrison, I.: "An investigation of the technoeconomic impact of internal combustion engine based cogeneration systems on the energy requirements and greenhouse gas emissions of the Canadian housing stock", Applied Thermal Engineering, Vol. 87, 2015, pp 505-518.

[10] Arbabi, P., Abbassi, A., Mansoori, Z., Seyfi, M.: "Joint numerical-technical analysis and economical evaluation of applying small internal combustion engines in combined heat and power (CHP)", Applied Thermal Engineering, Vol. 113, 2017, pp 694-704.

[11] Crawley, D.B., Lawrie, L.K., Winkelmann, F.C., Buhl, W.F., Huang, Y.J., Pedersen, C.O., Strand, R.K., Liesen, R.J., Fisher, D.E., Witte, M.J., et al.: "Energyplus: creating a new-generation building energy simulation program", Energy and Buildings, Vol. 33, No. 4, 2001, pp 319-331.

[12] Bojić, M., Nikolić, N., Nikolić, D., Skerlić, J., Miletić, I.: "Toward a positive-netenergy residential building in Serbian conditions", Applied Energy, Vol. 88, No. 7, 2011, pp 2407-2419. 
A preliminary assessment of residential application of internal combustion engine based cogeneration in serbian climatic conditions with building simulation program

[13] Lukić, N., Nikolić, N., Timotijević, S., Tasić, S.: "Influence of an unheated apartment on the heating consumption of residential building considering current regulations case of Serbia", Energy and Buildings, Vol. 155, 2017, pp 16-24.

[14] Nikolić, N., Lukić, N., Dagović, V., Nešović, A., Matejić, M.: "Impact of the methods of occupancy schedule defining on people heat gains within a student dormitory", $49^{\text {th }}$ International Congress and Exhibition on Heating, Refrigeration and Air-conditioning, Belgrade, Serbia, 2018, $5^{\text {th }}-7^{\text {th }}$ of December, pp 207-216.

[15] ASHRAE Handbook of Fundamentals, ASHRAE, Atlanta, 2005.

[16] Mudie, S., Essah, E.A., Grandison, A., Felgate, R.: "Electricity use in the commercial kitchen", International Journal of Low-Carbon Technologies, Vol. 11, No. 1, 2016, pp 66-74.

[17] Gorenje, Clothes washer, Technical Data. Available: https://partners.gorenje.com/fts/PiPki.aspx?ident=729291\&jezik=sr $\quad$ [Accessed: 10/01/2019].

[18] Gorenje, Clothes dryer, Technical Data. Available: https://partners.gorenje.com/fts/PiPki.aspx?ident=730016\&jezik=sr $\quad$ [Accessed: 10/01/2019].

[19] Candy, Dishwasher, Technical Data. Available: http://www.candy.rs/sr_RS latin/aparati/operi-osusi/sudomasine/lcatalog/21698127/cdpm-77735 [Accessed: 10/01/2019].

[20] Recknagel, H., Sprenger, E., Schramek, E.-R.: "Taschenbuch für Heizung und Klimatechnik", R. Oldenbourg Industrieverlag GmbH, München, 2011.

[21] Viessmann, IC cogeneration unit, Technical Data. Available: https://www.viessmann.de/de/wohngebaeude/kraft-waermekopplung/blockheizkraftwerk/vitobloc-200-em-9-20.html [Accessed: 30/01/2019].

[22] EPS. Electricity prices in the Republic of Serbia. Available: http://www.epssnabdevanje.rs/kupci/Documents/20170828_Odluka\%20o\%20regulisanoj\%20ceni\%2 0EE\%20na\%20garantovanom\%20snabdevanju\%2001.10.2017.pdf [Accessed: 16/02/2019].

[23] Eurostat. Electricity prices for household consumers. Available: http://appsso.eurostat.ec.europa.eu/nui/show.do?dataset=nrg_pc_204\&lang=en [Accessed: 16/02/2019].

[24] Eurostat. Gas prices for household consumers. Available: http://appsso.eurostat.ec.europa.eu/nui/show.do?dataset=nrg_pc_202\&lang=en [Accessed: 16/02/2019].

[25] Feed in tariffs in the Republic of Serbia. Available: https://www.energetskiportal.rs/ministarstvo/fid-in-tarife/ [Accessed: 18/02/2019]. 